\title{
PENGARUH KEPALA SEKOLAH YANG BERJIWA WIRAUSAHA TERHADAP PENGEMBANGAN SEKOLAH
}

\author{
Mohd. Winario \\ Universitas Tabrani Pekanbaru, Indonesia \\ winariomohd.winario@gmail.com. \\ Irawati \\ Universitas Islam Negeri Sultan Syarif Kasim Riau, Indonesia \\ irasofyanpku@gmail.com
}

\begin{abstract}
ABSTRAK
Pendidikan merupakan hal yang sangat penting bagi kemajuan peradaban bangsa dan negara, dari pendidikan juga akan merubah dunia, sehingga untuk mencapainya, maka pendidikan harus ditata dan dikelola dengan baik dan teratur sesuai dengan fungsi fungsi manajemen, mulai dari perencanaan, pengorganisasian, melaksanakan, dan fungsi pengawasan, peran pengelola pendidikan disini menjadi penting untuk dilihat bagaimana mereka mengelola pendidikan yang dipimpinnya. Pada Penelitian ini penulis mengambil permasalahan tentang bagaimana pengaruh kepala sekolah yang berjiwa kewirausahaan terhadap pengembangan sekolah yang dipimpinnya. Penelitian ini dilakukan dengan pendekatan analisis deskriptif kualitatif. Hasil dari penelitian ini menunjukkan bahwa kriteria kepala sekolah sesuai dengan Permendiknas No.13 tahun 2007, memiliki lima dimensi kompetensi, yaitu kepribadian, manajerial, kewirausahaan, supervisi, dan sosial salah satunya adalah memiliki jiwa kewirausahaan, sehingga setiap kepala sekolah/madrasah haru memiliki jiwa kewirausahaan ini dan Kepala sekolah adalah desicion maker dan regulator merupakan faktor penentu kesuksesan sekolah, sehingga jiwa kewirausahaan kepala sekolah untuk kemandirian dan pengembangan sekolah sangat diperlukan, selain kepala sekolah setiap stakeholder harus bersinergi untuk kemjuan dan pengembangan sekolah.
\end{abstract}

Kata Kunci: Kepala Sekolah, Jiwa Wirausaha, Pengembangan.

\section{A. PENDAHULUAN}

Pendidikan merupakan hal yang sangat penting bagi kemajuan peradaban bangsa dan negara, dari pendidikan juga akan merubah dunia, sehingga untuk mencapainya, maka pendidikan harus ditata dan dikelola dengan baik dan teratur sesuai dengan fungsi fungsi manajemen, mulai dari perencanaan pengorganisasian (planning), (organizing), melaksanakan (actuating), dan fungsi pengawasan (controlling), peran pengelola pendidikan disini menjadi 
penting untuk dilihat bagaimana mereka mengelola pendidikan yang dipimpinnya.

Kualitas suatu pendidikan akan tercapai apabila komponen-komponen untuk meningkatkan kualitas pendidikan memenuhi syarat tertentu. Komponen yang berperan dalam peningkatan mutu pendidikan salah satunya adalah kepala sekolah, tenaga pendidik yang berkualitas juga, yaitu yang mampu menjawab tantangantantangan dengan cepat dan bertanggung jawab. Kepala Sekolah dan Tenaga pendidik mempunyai peran yang sangat strategis dalam pembentukan pengetahuan, ketrampilan, dan karakter peserta didik, karena itu kepala sekolah dan tenaga pendidik yang profesional akan melaksanakan tugasnya secara profesional sehingga menghasilkan siswa yang lebih berkualitas juga.

Sebagaimana Danim (2002:45) menyatakan kepala sekolah adalah guru yang mendapat tugas tambahan sebagai kepala sekolah. Kompleksnya tugastugas sekolah membuat lembaga itu tidak mungkin lagi berjalan baik tanpa kepala sekolah profesional dan berjiwa inovatif. Pencapaian tujuan sekolah erat kaitannya dengan upaya-upaya yang dilakukan kepala sekolah dalam menjalankan tugasnya. Upaya kepala sekolah untuk mengembangkan sekolah dapat dilakukan dengan cara inovatif.

Salah satu kompetensi kepala sekolah yang harus dikuasai adalah kewirausahaan yang akan mendukung tugas dan fungsinya dalam meningkatkan mutu pendidikan. Kewirausahaan dalam bidang pendidikan focus pada karakteristiknya (sifatnya) seperti inovatif, bekerja keras, motivasi yang kuat, pantang menyerah dan selalu mencari solusi terbaik, dan memiliki naluri kewirausahaan. Dengan harapan sifat-sifat tersebut dapat bermanfaat untuk mengembangkan dan mencapai keberhasilan dalam melaksanakan tugas pokok dan fungsi sebagai pemimpin.

Kompetensi yang menuntut kepala sekolah mampu melakukan inovasi dan mewirausahakan sekolahnya adalah kompetensi kewirausahaan kepala sekolah, dalam Permendiknas Nomor 13 Tahun 2007 terdiri atas lima tugas kompetensi kewirausahaan kepala sekolah, yaitu Menciptakan inovasi yang berguna bagi pengembangan sekolah atau madrasah, Berkerja keras untuk keberhasilan sekolah atau madrasah sebagai organisasi pembelajaran yang efektif, memililki motivasi yang kuat untuk sukses dalam melaksanakan tugas pokok dan fungsinya sebagai pemimpin sekolah atau madrasah, pantang menyerah dan selalu mencari solusi terbaik dalam menghadapi kendala yang dihadapi sekolah atau madrasah, dan memiliki naluri kewirausahaan dalam mengelola kegiatan produksi atau jasa sekolah atau madrasah sebagai sumber belajar peserta didik.

Peraturan Menteri Pendidikan Nasional Nomor 13 Tahun 2007 tentang Standar Kepala sekolah menegaskan bahwa seorang kepala sekolah harus memiliki lima dimensi kompetensi yaitu: kompetensi kepribadian, kompetensi manajerial, kompetensi kewirausahaan, kompetensi supervisi, 
dan kompetensi sosial. Pada era otonomi daerah para pengelola pendidikan khususnya para Kepala Sekolah dituntut untuk mampu bertindak secara lebih mandiri dan profesional. Mereka dituntut untuk berani menanggung resiko atas keputusan-keputusan yang diambilnya. Mereka tidak boleh banyak menunggu petunjuk, perintah dan mengharapkan bantuan dari atas atau dari pusat.

Hal ini juga selaras dengan pernyataan Menteri Pendidikan dan Kebudayaan Muhadjir Effendy mendorong kepala Sekolah Menengah Kejuruan untuk memiliki jiwa wirausaha atau mental wirausaha pendidikan.

Ke depannya, kepala sekolah dimungkinkan untuk tidak mengajar, cukup jadikan sekolah lebih maju, bagaimana bisa memajukan sekolah. Semoga ke depan [tentang kepala sekolah] bisa ditangani dengan khusus,"ujarnya dalam keterangan resmi, Selasa (7/11/2017)." (http://kabar24.bisnis.com/).

Sehingga kepala sekolah dalam memajukan dan mengembangkan tidak perlu lagi bertanya-tanya ke atas atau dari pusat untuk pengembangan sekolah, yang penting sekolah yang dipimpinnya bisa maju dan berkembang dan feedback-nya tentu akan ke sekolah yang dipimpinnya juga, bisa lebih mandiri dalam mengatasi masalah finansial instansinya, apalagi melihat kondisi sekarang dana dari pemerintah sering terlambat turun ke sekolah dan ini tentunya akan menghambat pergerakan sekolah dan berdampak pada kelesuan tenaga pendidik dalam mengajar anak didiknya.

Melihat fenomena di atas, maka pada penelitian ini penulis mengambil permasalahan tentang bagaimana pengaruh kepala sekolah yang berjiwa kewirausahaan terhadap pengembangan sekolah yang dipimpinnya.

\section{B. KAJIAN TEORITIS}

Kepemimpinan berasal dari kata pemimpin maksudnya adalah orang yang dikenal oleh dan berusaha mempengaruhi para pengikutnya untuk merealisir visinya. (Syaiful, 2009: 114)

Sedangkan kepemimpinan kepala sekolah berbasis kewirausahaan adalah suatu praktek kepemimpinan pendidikan (kepala sekolah) dengan menerapkan prinsip-prinsip kewirausahaan. Sejalan dengan desentralisasi pendidikan dan otonomi sekolah, di antaranya dengan penerapan manajemen berbasis sekolah (school based management), kemampuan kewirausahaan menjadi sangat penting dan sangat menentukan bagi keberhasilan sekolah. Pemerintah pun menetapkan kewirausahaan sebagai bagian dari kompentensi kepala sekolah (Peraturan Menteri Pendidikan Nasional No. 13 Tahun 2007).

Seorang kepala sekolah adalah seorang pemimpin yang akan menentukan langkah-langkah pendidikan yang efektif di lingkungan sekolah (Juairiah, 2006). Sedangkan menurut Wagiman (2005) kepala sekolah adalah seorang tenaga fungsional yang diberi tugas memimpin suatu lembaga sekolah yang 
menyelenggarakan proses belajar mengajar.

$$
\text { Indikator kompetensi }
$$

kewirausahaan kepala sekolah, menurut Permendiknas tersebut, meliputi (a) menciptakan inovasi yang berguna bagi pengembangan sekolah/madrasah; (b) bekerja keras untuk mencapai keberhasilan sekolah/ madrasah sebagai organisasi pembelajar yang efektif; (c) memiliki motivasi yang kuat untuk sukses dalam melaksanakan tugas pokok dan fungsinya sebagai pemimpin sekolah/madrasah; (d) pantang menyerah dan selalu mencari solusi terbaik dalam menghadapi kendala yang dihadapi sekolah/madrasah; dan (e) memiliki naluri kewirausahaan dalam mengelola kegiatan sekolah/madrasah sebagai sumber belajar peserta didik.

Definisi

kewirausahaan (entrepreneurship) juga sudah banyak dilontarkan para pakar, khususnya pakar manajemen. Hirich, Peters, dan Shepherd (2008: 10) mengartikan kewirausahaan sebagai "proses penciptaan sesuatu yang baru pada nilai yang menggunakan waktu dan upaya yang diperlukan, menanggung risiko keuangan, fisik, serta risiko sosial yang mengiringi imbalan moneter yang dihasilkan, serta kepuasan dan kebebasan pribadi."

Kasmir (2006: 19) menyatakan arti wirausahawan secara sederhana yaitu orang yang berjiwa berani mengambil resiko untuk membuka usaha dalam berbagai kesempatan. Jiwa kewirausahaan mendorong minat seseorang untuk mendirikan dan megelola usaha secara sederhana.
Zimmerer sebagimana dikutip oleh Suryana (2003:7) mengungkapkan "Entrepreneurship is the result of a disciplined, systematic process of applying creativity and innovations to needs and opportunities in the market place". Kewirausahaana dalah hasil dari sebuah proses, disiplin sistematis menerapkan kreativitas dan inovasi dengan kebutuhan dan peluang di pasar.

Berdasarkan pengertian tersebut dapat dijelaskan bahwa kewirausahaan dalam pendidikan merupakan proses dari kerja keras, kreativitas dan inovatif secara terus menerus yang dilakukan oleh pihak sekolah, terutama oleh kepala sekolah sebagai pimpinan tertinggi disebuah instansi agar tercapai visi, misi, tujuan dan target yang akan dicapai maksimal, sehingga memberikan pengaruh bagi pengembangan kualitas maupun kuantitas sekolah.

Dalam mengembangkan jiwa kewirausahaan di sekolah, maka kepala sekolah, tenaga kependidikan, guru dan warga sekolah lainnya perlu dilatih dan dibiasakan untuk berperilaku kewirausahaan. Kepala sekolah sebagai pemimpin organisasi sekolah, harus mampu membimbing warga sekolah dan mengembangkan sikap kewirausahaan sesuai dengan tugas dan fungsi masing-masing warga sekolah. Kepala sekolah yang berjiwa wirausaha diharapkan mampu mengorganisir dan mensinerjikan sumber usaha-usaha untuk mendirikan usaha atau programprogram memajukan sekolah.

Dengan memiliki jiwa atau corak kewirausahaan, maka kepala sekolah 
diharapakan dapat mendorong warga sekolah agar memiliki motivasi, optimisme dan berlomba untuk menciptakan cara-cara baru, gagasan baru yang lebih efisien, efektif, inovatif, fleksibel, dan adaptif dalam setiap kondisi dan keadaan. Komariah (2008:20) mengungkapkan inovasi adalah suatu gagasan, barang, kejadian, teknik-teknik atau metode-metode atau praktik yang diamati, disadari, dirasakan, dan diterima sebagai hal yang baru oleh seseorang atau kelompok (masyarakat), baik sebagai hasil discovery maupun invention.

Mulyasa

(2008:118)

mengungkap-kan kepala sekolah sebagai inovator akan tercermin dari cara-cara ia melakukan pekerjaanya secara konstruktif, kreatif, delegatif, integrative, rasional, objektif, pragmatis, keteladanan, disiplin, serta adaptable dan fleksibel. Tugas kepala sekolah sebagai inovator yaitu kemampuan kepala sekolah untuk mencari dan menemukan gagasan baru yang relevan dengan tujuan untuk pembaharuan sekolah yang lebih baik dan berkualitas. Dalam menjalankan perannya sebagai inovator pendidikan kepala sekolah dituntut untuk aktif bekerja, berpikir kreatif, inovatif, dan memanfaatkan peluang serta mampu merespon lingkungan dengan baik. Dengan hal tersebut kepala sekolah dapat melakukan dan menghadapi perubahan yang terjadi, sesuai dengan apa yang diharapkan oleh lingkungan atau masyarakat.

Selanjutnya pembahasan mengenai peran kepala sekolah sebagai motivator. Menurut Robbins (2003:212) definisi motivasi adalah sebagai proses yang ikut menetukan intensitas, arah dan ketekunan individu dalam usaha mencapai sasaran. Selanjutnya Siagian (2003:108) mengungkapkan motivasi adalah keseluruhan proses pemberian dorongan bekerja kepada para bawahan sedemikian rupa sehingga mereka mau bekerja dengan ikhlas demi tercapainya tujuan organisasi dengan efisien dan ekonomis.

Jadi pada intinya, orang yang dapat memberikan dorongan kepada bawahannya untuk bekerja sesuai dengan tujuan dan targetnya merupakan pemimpin yang sukses mejalankan perannya sebagai motivator. Kepala sekolah yang memiliki jiwa wirausahaan harus mampu mendorong warga sekolahnya untuk berkerja lebih baik. Tetapi peran kepala sekolah sebagai motivator bukan saja harus mendorong warganya untuk berkerja sesuai dengan yang diharapkan organisasi, kepala sekolah juga harus menjadi contoh teladan yang baik kepada warga sekolah, sehingga warga sekolah terdorong untuk mencontoh kepala sekolah sebagai panutannya.

Sunyoto (2012:198) menjelaskan tujuan pemberian motivasi adalah mendorong gairah dan semangat kerja karyawan, meningkatkan moral dan kepuasan kerja karyawan, meningkatkan produktivitas kerja karyawan, mempertahankan loyalitas dan kestabilan karyawan perusahaan, meningkatkan kedisiplinan dan menurunkan tingkat absensi karyawan, menciptakan suasana dan hubungan kerja yang baik, meningkatkan kreativitas dan partisipasi karyawan, 
meningkatkan kesejahteraan karyawan, mempertinggi rasa tanggung jawab keryawan terhadap tugas-tugasnya. Alma (2005:74) menyatakan salah satu teori motivasi adalah teori humanistik yaitu teori kebutuhan Abraham Maslow, sebagaimana dikutip oleh Alma mengungkapkan bahwa hirarki kebutuhan manusia dapat dipakai untuk melukiskan dan meramalkan motivasinya

$$
\text { Mulyasa }
$$

mengungkapkan motivasi kepala sekolah ditumbuhkan melalui pengaturan lingkungan fisik, pengaturan suasana kerja, disiplin, dorongan, penghargaan secara efektif, dan penyediaan berbagai sumber belajar melalui pengembangan Pusat Sumber Belajar (PSB). Dalam menjalankan perannya sebagai motivator kepala sekolah diharapkan mampu mendorong dan mengubah warga sekolah yang sebelumnya bekerja belum produktif menjadi lebih produktif dan berkualitas.

Kepala sekolah sebagai motivator harus mampu membangkitkan produktivitas warga sekolah. Kepala sekolah dengan memotivasi warga sekolah diharapkan dapat menjadikan memicu terbentuknya jiwa kewirausahaan.

Dasar hukum kewirausahan juga bisa kita lihat pada al-Quran dan hadits sebagai berikut:

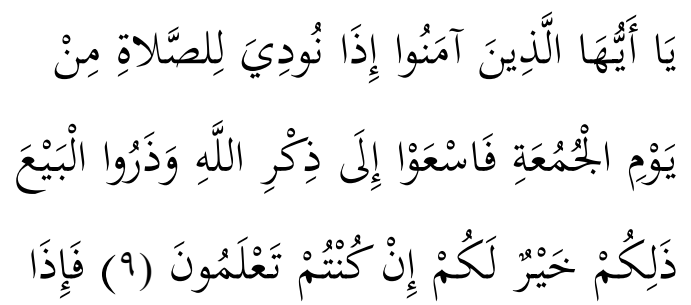

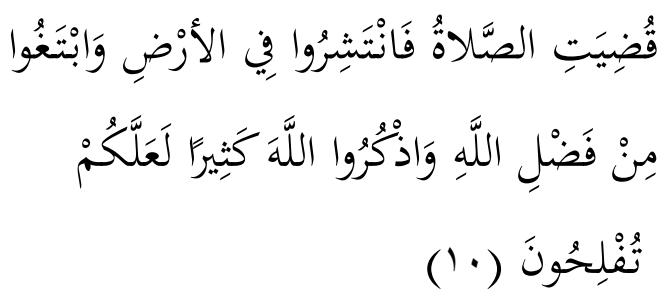

Artinya:"Hai orang-orang beriman, apabila diseru untuk menunaikan shalat Jum'at, Maka bersegeralah kamu kepada mengingat Allah dan tinggalkanlah jual beli. yang demikian itu lebih baik bagimu jika kamu mengetahui. Apabila telah ditunaikan shalat, Maka bertebaranlah kamu di muka bumi; dan carilah karunia Allah dan ingatlah Allah banyak-banyak supaya kamu beruntung." (al-Jumuah: 9-10).

Artinya: "Perhatikan olehm sekalian perdagangan, sesunguhnya di dunia perdagangan itu ada sembilan dari sepuluh pintu rizki.(HR. Ahmad).

Artinya: Kemudian Pernah Nabi ditanya Oleh para sahabat: "pekerjaan apa yang paling baik ya Rasulullah ?"beliau menjawab "Seorang bekerja dengan tangannya sendiri dan setiap jual beli yang bersih."(HR. Al Bazzar).

Dari ayat dan hadits di atas dapat dijelaskan bahwa anjuran kewirausahaan ada pada al-Qur'an dan hadits Nabi Muhammad shallahu alaihi wassalam, pada surat al-Jumat ayat 9, dijelaskan bahwa kita selaku orang muslim untuk meninggalkan perkerjaan jual beli, jual beli disini adalah bisnis atau kewirausahaan dan bersegera meninggalkannya. Pada ayat 10 dijelaskan apabila telah melaksanakan shalat untuk kembali bertebaran ke muka bumi untuk mencari karunia 
Allah, dari ayat ini dijelaskan supaya antara dunia dan akhirat agar seimbang.

Pada hadits juga dijelaskan bahwa kalau mau mencari rezeki sumber yang paling banyak adalah dengan jalan perniagaan atau perdagangan dan dilanjutkan dengan hadits yang lainnya adlah perdagangan merupakan pekerjaan yang paling baik, tentunya jika dilakukan dengan cara yang baik dan dengan jalan yang sesuai dengan syariah islam.

Hal ini juga didukung dengan surat an-Nisa': 29.

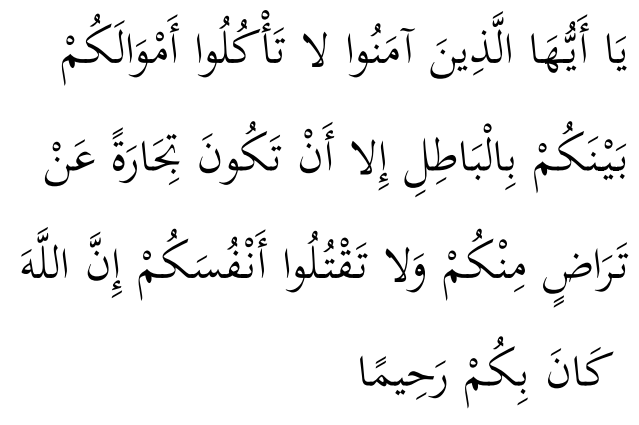

Artinya: "Wahai orang-orang yang beriman! Janganlah kamu saling memakan harta sesamamu dengan jalan yang batil (tidak benar), kecuali dengan jalan perdagangan yang berlaku atas dasar suka sama-suka di antara kamu. Dan janganlah kamu membunuh dirimu. Sesungguhnya Allah Maha Penyayang kepadamu. (an-Nisa: 29)

Dari ayat di atas dijelaskan bahwa ketika kita berniaga atau berbisnis seorang wirausaha harus sesuai dengan yang disyariatkan, diantaranya dengan cara jalan yang hak (benar) dan didasarkan atas dasar suka sama suka, tidak dengan cara yang batil.

\section{METODE}

Penelitian ini dilakukan di Kota Pekanbaru dengan menggunakan pendekatan deskriptif kualitatif yang berbentuk observasi (pengamatan) dan tidak melibat kepala sekolah secara langsung (non partisipan) dan melihat kasus yang terjadi di beberapa sekolah di Pekanbaru, kemudian penulis melakukan analisis untuk memperoleh pengertian yang mendalam mengenai situasi dan kondisi dan maksud sesuatu atau objek yang telah diteliti.

\section{PEMBAHASAN}

Berdasarkan Peraturan Menteri Pendidikan Nasional nomor 13 tahun 2007, ada lima dimensi kompetensi kepala sekolah yaitu kompetensi kepribadian, kompetensi manajerial, kompetensi kewirausahaan, kompetensi supervisi, dan kompetensi sosial, yang menjadi fokus penelitian ini adalah pada dimensi kompetensi kewirausahaan, seperti dapat dilihat pada tabel di bawah ini:

Tabel 1

Dimensi Kompetensi Kepala Sekolah

\begin{tabular}{|c|lr|}
\hline $\begin{array}{c}\text { Dimensi } \\
\text { Kompet } \\
\text { ensi }\end{array}$ & \multicolumn{2}{|c|}{ Kompetensi } \\
\hline $\begin{array}{c}\text { Kewirau } \\
\text { sahaa } \\
\mathrm{n}\end{array}$ & $\begin{array}{l}\text { 1. Menciptakan inovasi yang } \\
\text { berguna }\end{array}$ \\
& $\begin{array}{l}\text { pengembangan } \\
\text { sekolah/madrasah. }\end{array}$ \\
& 2. Bekerja keras untuk \\
& mencapai keberhasilan \\
& sekolah/madrasah sebagai \\
& organisasi pembelajar \\
& yang efektif. \\
& 3. Memiliki motivasi yang \\
& kuat untuk sukses dalam \\
& melaksanakan tugas pokok \\
dan fungsinya sebagai & pemimpin \\
& sekolah/madrasah. \\
\hline
\end{tabular}




\begin{tabular}{|l|lr|}
\hline 4. Pantang & menyerah & dan \\
selalu mencari & solusi \\
terbaik dalam menghadapi & kendala yang dihadapi \\
sekolah/madrasah. & \\
5. Memiliki & naluri \\
kewirausahaan & dalam \\
mengelola & kegiatan \\
produksi/jasa & \\
sekolah/madrasah & sebagai \\
sumber belajar & peserta \\
didik. &
\end{tabular}

Sumber: Permendiknas No. 13 Tahun 2007

Dari tabel tersebut di atas dapat dijelaskan bahwa seorang kepala sekolah harus memiliki jiwa kewirausahaan, dengan kompetensi tersebut kepala sekolah bisa mengembangkan sekolah atau madrasah, mencapai keberhasilan sekolah atau madrasah sebagai pembelajar yang efektif, melaksanakan tugas pokok dan fungsinya sebagai pemimpin sekolah atau madrasah, pantnag menyerah dan selalu mencari solusi terbaik dalam menghadapi kendala yang dihadapi, dan memiliki naluri kewirausahaan dalam mengelola kegiatan sebagai sumber belajar peserta didik.

Pada pembahasan ini penulis menganalisis dari hasil pengamatan (observasi) yang penulis lakukan di beberapa sekolah yang ada di Pekanbaru. Dari hasil pengamatan penulis dapat dijelaskan kondisi sekolah yang ada di Pekanbaru, terlihat sekolah mana yang dipimpin oleh kepala sekolah yang memiliki jiwa kewirausahaan dan kepala sekolah yang jiwa kewirausahaannya rendah.
Dengan melihat mana sekolah maju dan mana sekolah yang pengembangannya stagnan, atau bahkan ada sekolah yang cenderung menurun, hal ini merupakan salah satu indikator pimpinan dari sekolah tersebut dipimpin oleh kepala sekolahnya.

Keberhasilan sekolah tidak hanya dari pemimpinnya dalam hal ini kepala sekolah, hal ini juga didukung juga dengan tenaga pendidik, para siswa, alumni, orang tua/wali dan stakeholder yang terlihat dalam sekolah tersebut. Stakeholder tersebut ikut terlibat bagi pengembangan dan pertumbuhan sekolah, karena sekolah adalah sebuah organisasi yang harus saling bersinergi dalam membangun sebuah sistem yang dikembangkan sekolah. Peran kepala sekolah menjadi penting dalam pengembangan sekolah jika setiap stakeholder saling bersinergi, karena kepala sekolah adalah sang regulator atau dicision maker pada setiap kebijakan.

Untuk pengembangan sekolah, kepala sekolah seharusnya melibatkan unsur kewirausahaan pada setiap kegiatan, selain kegiatan akan lebih menarik juga dari sisi kemandirian ekonomi pada sekolah, juga efeknya adalah pada siswa, pola pikir siswa juga akan meniru atasannya (kepala sekolah).

Kepala sekolah yang memiliki jiwa wirausaha pada umumnya mempunyai tujuan dan pengharapan tertentu yang dijabarkan dalam visi, misi, tujuan, sasaran dan rencana strategis yang realistik. Antara visi, misi, tujuan, dan sasaran ini saling sinergi dan tergambar dan 
terdeskripsikan. Realistik berarti tujuan disesuaikan dengan sumber daya, baik SDM dan sumberdaya pendukung lainnya yang dimiliki. Semakin jelas tujuan yang ditetapkan semakin besar peluang untuk dapat merealisasikan. Dengan demikian, kepala sekolah yang berjiwa wirausaha harus memiliki tujuan yang jelas dan terukur dalam mengembangkan sekolah.

Untuk mengetahui apakah tujuan tersebut dapat dicapai maka visi, misi, tujuan dan sasarannya dikembangkan ke dalam indikator yang lebih terinci dan terukur untuk masing-masing aspek atau dimensi, dimensinya seperti pada Permendiknas No. 13 Tahun 2007. Dari indikator tersebut juga dapat dikembangkan menjadi programprogram dan sub-program yang akan lebih memudahkan implementasinya dalam pengembangan sekolah/madrasah.

\section{E. KESIMPULAN}

Dari pembahasan tersebut di atas, terkait pengaruh kepala sekolah yang memiliki jiwa kewirausahaan terhadap pengembangan sekolah, dapat penulis simpulkan, sebagai berikut:

1. Kriteria kepala sekolah sesuai dengan Permendiknas No.13 tahun 2007, memiliki lima dimensi kompetensi, yaitu kompetensi kepribadian, kompetensi manajerial, kompetensi kewirausahaan, kompetensi supervisi, dan kompetensi sosial salah satunya adalah memiliki jiwa kewirausahaan, sehingga setiap kepala sekolah/madrasah haru memiliki jiwa kewirausahaan ini.
2. Kepala sekolah adalah desicion maker dan regulator merupakan faktor penentu kesuksesan sekolah, sehingga jiwa kewirausahaan kepala sekolah untuk kemandirian dan pengembangan sekolah sangat diperlukan, selain kepala sekolah setiap stakeholder harus bersinergi untuk kemjuan dan pengembangan sekolah.

Selanjutnya melalui tulisan ini, penulis memberikan saran atau rekomendasi untuk kemajuan dan pengembangan sekolah yang ada di pekanbaru khususnya dan indonesia umumnya sebagai berikut:

1. Pemerintah selaku pemberi kebijakan bagi pendidikan di Indonesia, sudah seharusnya berperan sebagai fungsi kontrol melihat dan mengevaluasi untuk kemajuan dan pengembangan sekolah, melihat mana sekolah yang memiliki jiwa kewirausahaan dan mana yang tidak.

2. Selain pemerintah mengevaluasi, seharusnya pemerintah juga memberikan pelatihan bagi setiap kepala sekolah yang ada di indonesia, baik yang negeri maupun yang swasta, agar kepala sekolah yang jiwa kewirausahaannya rendah akan termotivasi.

3. Memberikan reward kepada kepala sekolah yang tingkat keberhasilan bagi pengembangan sekolah.

4. Hendaknya kepala sekolah mulai berpikir cerdas untuk bisa mandiri dengan berinovasi bagi pengembangan sekolahnya.

5. Hendaknya kepala sekolah dalam pengembangan pada setiap kegiatan dikaitkan dengan kewirausahaan. 
6. Semua stakeholder seharusnya bersinergi dengan kebijakan kepala sekolah yang bersifat kewirausahaaan untuk kemajuan dan pengembangan sekolah.

\section{DAFTAR PUSTAKA}

1. Alma,

Buchari. 2005. Kewirausahaan: Edisi Revisi, Bandung : Alfabeta.

2. Danim, Sudarman. 2002. Inovasi Pendidikan dalam Upaya Peningkatan Profesional Tenaga Kependidikan. Bandung : $\quad \mathrm{CV}$ Bandung Pustaka Setia.

3. Hirsrich, Robert D., Peters, Michael P., dan Shepherd, Dean A. 2008. Entrepreneurship . Jakarta: Penerbit Salemba Empat.
4. Kasmir. 2011. Kewirausahaan. Jakarta: Rajagrafindo Persada.

5. Mulyasa. 2003. Menjadi Kepala Sekolah Profesional Dalam Menyuskseskan MBS dan KBK. Bandung: Remaja Rosdakarya.

6. Peraturan Menteri Pendidikan Nasional No. 13 Tahun 2007.

7. Sunyoto, Danang. 2012. Manajemen Sumber Daya Manusia. Yogyakarta: Center for Academic Publishing Service.

8. Suryana. 2003. Kewirausahaan: Pedoman Praktis, Kiat dan Proses Menuju Sekolah. Jakarta: PT. Salemba Empat.

9. Syaiful Sagala. 2009. Kepemimpinan Profesional Guru dan Tenaga Kependidikan, Bandung: Alfabeta. 